\title{
Implementasi E Government Pemerintahan Desa Dalam Administrasi Pelayanan Publik (Studi Kasus Web Site Desa Kanie Kecamatan Maritengngae Kabupaten Sidenreng Rappang)
}

\author{
Ahmad Mustanir*), Andry Arya Nugraha, \\ Nursyamsi
}

\begin{abstract}
ABSTRAK
Sistem informasi berkembang semakin pesat ditandai adanya pemanfaatan internet. Internet sebagai media penyampai informasi keberadaanya kini sudah menjadi kebutuhan. Manfaat internet cukup besar dirasakan terutama dalam dunia bisnis, hiburan, maupun pemeintahan. Desa Kanie salah satu desa yang terdapat di Kabupaten Sidenreng Rappang. Desa Kanie mengalami kendala dalam sistem pengenalan struktur organisasi, kegiatan-kegiatan, lokasi, maupun potensi-potensi yang ada di desa tersebut, yang saat ini hanya dikenal oleh masyarakat sekitar saja. Dengan perkembangan teknologi informasi yang semakin pesat maka Desa Kanie juga memerlukan sebuah media promosi yang bersifat online yang dapat juga disebut website promosi desa. Sehingga website promosi ini diharapkan dapat berjalan dengan baik maka akan mempermudah dalam mengenalkan potensi-potensi, maupun administrasi pelayanan publik, yang ada di Desa Kanie. Kegiatan pembuatan website dilakukan di Desa Kanie, Dusun Kanie 1 dan Dusun Labempa dilaksanakan pada Bulan Januari sampai Februari 2020.
\end{abstract}

Key Words : Administrasi, e-Government, Pelayanan Publik, Teknologi Informasi, Web Site 


\section{PENDAHULUAN}

Desa adalah kesatuan masyarakat hukum yang memiliki kewenangan untuk mengatur dan mengurus kepentingan masyarakat setempat berdasarkan asal usul dan Adat istiadat setempat yang diakui dalam sistem pemerintahan Nasional dan berada di daerah Kabupaten. Desa adalah pembagian wilayah admninistratif di Indonesia dibawah kecamatan yang dipimpin oleh kepala desa seperti halnya dengan Desa Kanie yang dipimpin oleh seorang Kepala Desa.

Sistem informasi berkembang semakin pesat ditandai adanya pemanfaatan internet. Internet sebagai media penyampai informasi keberadaanya kini sudah menjadi kebutuhan. Manfaat internet cukup besar dirasakan terutama dalaam dunia bisnis, hiburan, maupun pemeintahan. Desa Kanie salah satu desa yang terdapat di Kabupaten Sidenreng Rappang. Desa Kanie mengalami kendala dalam sistem pengenalan struktur organisasi, kegiatan-kegiatan, lokasi, maupun potensi-potensi yang ada di desa tersebut, yang saat ini hanya dikenal oleh masyarakat sekitar saja. Dengan perkembangan teknologi informasi yang semakin pesat maka Desa Kanie juga memerlukan sebuah media promosi yang bersifat online yang dapat juga disebut website promosi desa. Sehungga website promosi ini diharapkan dapat berjalan dengan baik maka akan mempermudah dalam mengenalkan potensi-potensi, maupun administrasi pelayanan publik yang ada di Desa Kanie. Kegiatan pembuatan website dilakukan di Desa Kanie, Dusun Kanie 1 dan Dusun Labempa pada Bulan Januari sampai Februari 2020.

Sistem informasi merupakan sebuah rangkaian prosedur formal dimana data dikelompokkan, diproses menjadi informasi dan distribusikan kepada pemakai (Abdul Kadir, 2003). Sedangkan menurut Sutabari (2012), sistem informasi merupakan suatu sistem didalam suatu organisasi yang mempertemukan kebutuhan pengolahan transaksi harian yang mendukung fungsi operasi organisasi yang bersifat manajerial dengan kegiatan strategi dari suatu organisasi untuk dapat menyediakan laporan-laporan yang diperlukan oleh pihak tertentu. (Saidiman, Lubis, Razak, \& Mustanir, 2019) (Samad, Mustanir, \& Pratama, 2019) (Mustanir, Samad, Ibrahim, Jabbar, \& Juniati, 2019) (Dawabsheh, Mustanir, \& Jermsittiparsert, 2020) (Kholifah R \& Mustanir, 2019) (000166480, 2019) (000172479, 2019) (000166978, 2019) 
(000150190, 2019) (000154310, 2019) (Latif, Irwan, Mustanir, Ahmad, \& Sakkir, 2019) (Mustanir, Hamid, \& Syarifuddin, 2019d) (Latif, Mustanir, \& Irwan, 2019) (Mustanir, Hamid, \& Syarifuddin, 2019b) (Mustanir, Hamid, \& Syarifuddin, 2019a) (Mustanir et al., 2019) (Mustanir et al., 2019) (Mustanir, Ahmad; Ali, Akhwan; Yasin, 2018) (Sellang, Kamaruddin; Ahmad, Jamaluddin; Mustanir, 2019) (Mustanir, 2019a) (Mustanir, 2019b) (Mustanir, Mustanir, et al., 2019) (Sapri, Mustanir, Ibrahim, Adnan, \& Wirfandi, 2019) (Uceng, Erfina, Mustanir, \& Sukri, 2019) (Uceng, Ali, Mustanir, \& Nirmawati, 2019) (Mustanir, Sellang, Ali, Madaling, \& Mutmainna, 2018) (Mustanir, Dema, Syarifuddin, Meity, \& Wulandari, 2018) (Mustanir, 2015) (Mustanir, 2016a) (Mustanir, n.d.) (Irwan, Latif, Sofyan, Mustanir, \& Fatimah, 2019) (Latif, Irwan, Rusdi, Mustanir, \& Sutrisno, 2019).

Menurut Ila dan Erza (2017), metode yang paling mendukung terlaksananya sistem informasi adalah dengan mengembangkan administrasi pelayanan dengan sisten komputerisasi dengan memanfaatkan teknologi web. Data-data yang tersedia di kantor Desa / Kelurahan pun terkadang cukup sulit untuk dianalisis karena belum terkomputerisasi sehingga untuk mendapatkan informasi mengenai potensi yang ada di desa/kelurahan tentu membutuhkan waktu yang cukup lama untuk melakukan analisa. Padahal dengan kemajuan di bidang teknologi informasi seharusnya hal tersebut dapat diatasi sehingga informasi mengenai desa/ kelurahan dapat di ketahui degan cepat dan tepat ketika di butuhkan (Johan,dkk, 2015). (Mustanir, 2017a) (Mustanir, 2018a) (Mustanir, 2017b) (Mustanir, 2018b) (Mustanir \& Rusdi. Muhammad, 2019) (Damis Dadda, Mustanir, Nilwana, \& Ahmad, 2019) (Mustanir, Yasin, Irwan, \& Rusdi, 2018) (Mustanir \& Jaya, 2016a) (Mustanir, Ali, \& Yasin, 2018) (Mustanir \& Darmiah, 2016) (Mustanir \& Abadi, 2017) (Mustanir, Barisan, \& Hamid, 2017) (Mustanir \& Razak, 2017) (Barisan, Ramadhan, \& Mustanir, 2017) (Mustanir, 2016b) (Akhmad, Mustanir, \& Ramadhan, 2018) (Mustanir, Justira, Sellang, \& Muchtar, 2018) (Razak, Dahong, Ahmad, Dema, \& Mustanir, 2018) (Mustanir \& Yasin, 2018) (Mustanir, 2016c) (Mustanir \& Lubis, 2017) (Mustanir, Ahmad; Abadi, 2016) (Mustanir \& Jusman, 2016) (Mustanir, Abadi, \& Nasri, 2016) (Mustanir \& Jaya, 2016b) (Mustanir, Jermsittiparset, Ali, Hermansyah, \& Sakinah, 2020) (Parinya, Jermsittiparsert, \& Mustanir, 2019) (Mustanir, Hamid, \& Syarifuddin, 2019c). 


\section{SOLUSI PERMASALAHAN}

Desa Kanie mengalami kendala dalam sistem pengenalan struktur organisasi, kegiatan-kegiatan, lokasi, maupun potensi-potensi yang ada di desa tersebut, yang saat ini hanya dikenal oleh masyarakat sekitar saja. Dengan perkembangan teknologi informasi yang semakin pesat maka Desa Kanie juga memerlukan sebuah media promosi yang bersifat online yang dapat juga disebut website promosi desa. Sehungga website promosi ini diharapkan dapat berjalan dengan baik maka akan mempermudah dalam mengenalkan potensi-potensi, maupun administrasi pelayanan publik yang ada di Desa Kanie.

Dengan adanya website promosi Desa Kanie ini, dapat mengoptimalkan menyampaikan potensi-potensi maupun informasi yang berhubngan dengan Desa Kanie. Selain dari itu, dengan dibangunnya Website promosi Desa Kanie juga dapat mempermudah dalam memasarkan maupun mempromosikan produk informasi yang ada di Desa Kanie sehingga dapat dikenal oleh masyarakat luas khususnya masyarakat Desa Kanie dan tidak harus datang ke Desa tersebut cukup melihat melaui website promosinya bisa mengetehui informasi yang ada di Desa Kanie.

Berdasarkan uraian dari kendala-kendala maupun permasalahan yang telah di ungkapkan di atas, maka solusi yang dapat dilakukan adalah dengan membuat rencangan suatu sistem informasi potensi desa berbasis website yang di sebut dengan website desa. Deagan adanya website desa/kelurahan ini, maka diharapkan sistem informsi pendataan penduduk pada tingkat desa/kelurahan dapat membantu instansi pemerintah dalam melakukan pendataan penduduk dalam ruang lingkup sebuah desa/kelurahan,khususnya di Desa Kanie Kabupaten Sidenreng Rappang .

\section{METODE PELAKSANAAN}

Metode yang digunakan saat pengabdian meliputi pembuatan Website desa dan pelatihan aplikasi. Metode pembuatan aplikasi mengadopsi siklus hidup perangkat lunak, atau waterfall yaitu dengan melalui lima tahap yang berkesinambungan membentuk suatu siklus daur hidup perancangan perangkat lunak, lebih jelasnya dapat digambarkan dalam tabel 1 berikut : 
Tabel 1 : Permasalahan Sistem Informasi Desa Kanie

\begin{tabular}{|l|l|l|}
\hline \multicolumn{1}{|c|}{ Permasalahan mitra } & \multicolumn{1}{|c|}{ Solusi } & \multicolumn{1}{c|}{ Metode } \\
\hline Rendahnya sumber daya teknologi & Membuat aplikasi & Siklus hidup perangkat \\
pengelolaan data administrasi desa & Sistem Informasi & lunak \\
khususnya kependudukan dan surat & Desa & \\
menyurat & & \\
\hline
\end{tabular}

Sumber : Pelaksanaan Observasi Desa Kanie, 2019

\section{LOKASI DAN WAKTU PELAKSANAAN}

Kegiatan pembuatan website dilakukan di Desa Kanie, Dusun Kanie 1 dan Dusun Labempa Kecamatan Maritenggae yang dapat dilihat pada Gambar 1. Kegiatan ini dilaksanakan pada Bulan Januari-Februari 2020, mulai dari tahap persiapan, tahap pembuatan website Desa Kanie dengan potensi Desa yang dimiliki.

\section{Gambar 1. Lokasi Pembuatan Website Desa Kanie}

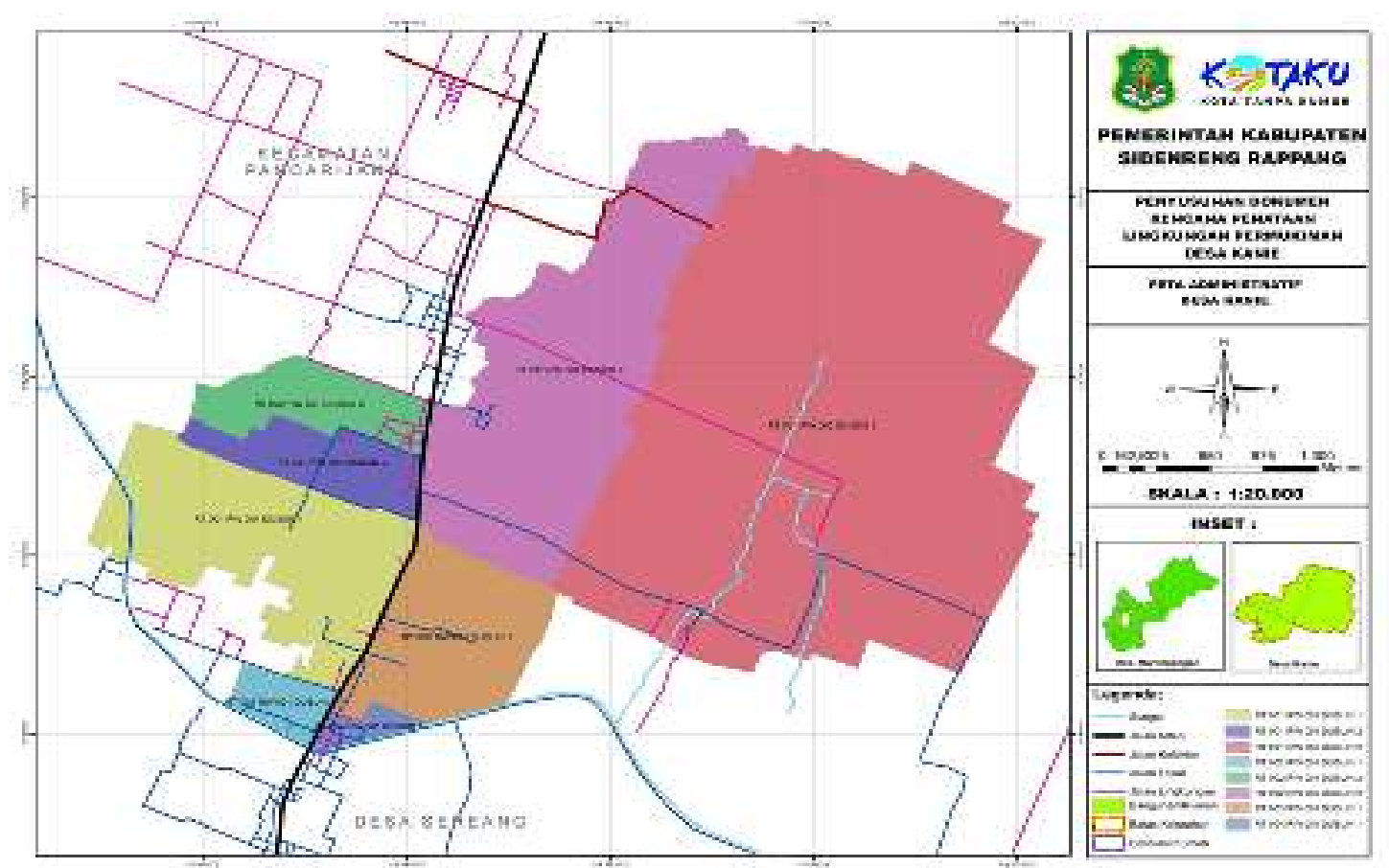


Tabel 2 : Waktu Pelaksanaan

\begin{tabular}{|c|c|c|c|c|c|}
\hline \multirow{2}{*}{ No } & \multirow{2}{*}{ Nama Kegiatan } & \multicolumn{3}{|c|}{ Januari } & \multirow{2}{*}{$\frac{\text { Februari }}{1}$} \\
\hline & & 2 & 3 & 4 & \\
\hline 1 & Observasi & & & & \\
\hline 2 & $\begin{array}{l}\text { Web Desa (Penginputan } \\
\text { Kependudukan, Artikel, Berita ) }\end{array}$ & & & & \\
\hline 3 & $\begin{array}{l}\text { Arsip Digital (Pengumpulan } \\
\text { Arsip, Pengniputan Arsip }\end{array}$ & & & & \\
\hline 4 & Manajemen BUMDES & & & & \\
\hline 5 & Potensi Desa & & & & \\
\hline 6 & Evaluasi & & & & \\
\hline
\end{tabular}

Sumber : Rencana Pelaksanaan tahun 2020

Adapun dalam pelaksanaan pembuatan website Desa Kanie oleh Mahasiswa Magang 1 Universitas Muhammadiyah Sidenreng Rappang telah dilalui beberapa tahap yaitu tahap sosialisasi keberadaan Website, pelaksanaannya yaitu meminta izin dan bekerja sama dengan pihak pemerintahan di lingkungan Desa Kanie untuk proses penginputan data penduduk yang sudah tercatat di kantor Desa, serta penginputan potensi desa. Maka hal ini menunjukkan bahwa tidak ada data yang tidak valid. Kantor Desa Kanie, Kecamatan Maritengngae, Kabupaten Sidenreng Rappang adalah tempat obyek perancangan sistem pembuatan Website oleh Mahasiswa Magang 1 Universitas Muhammadiyah Sidenreng Rappang.

Gambar 2 dan 3. Pembuatan Website Desa oleh Mahasiswa Magang Universitas Muhammadiyah
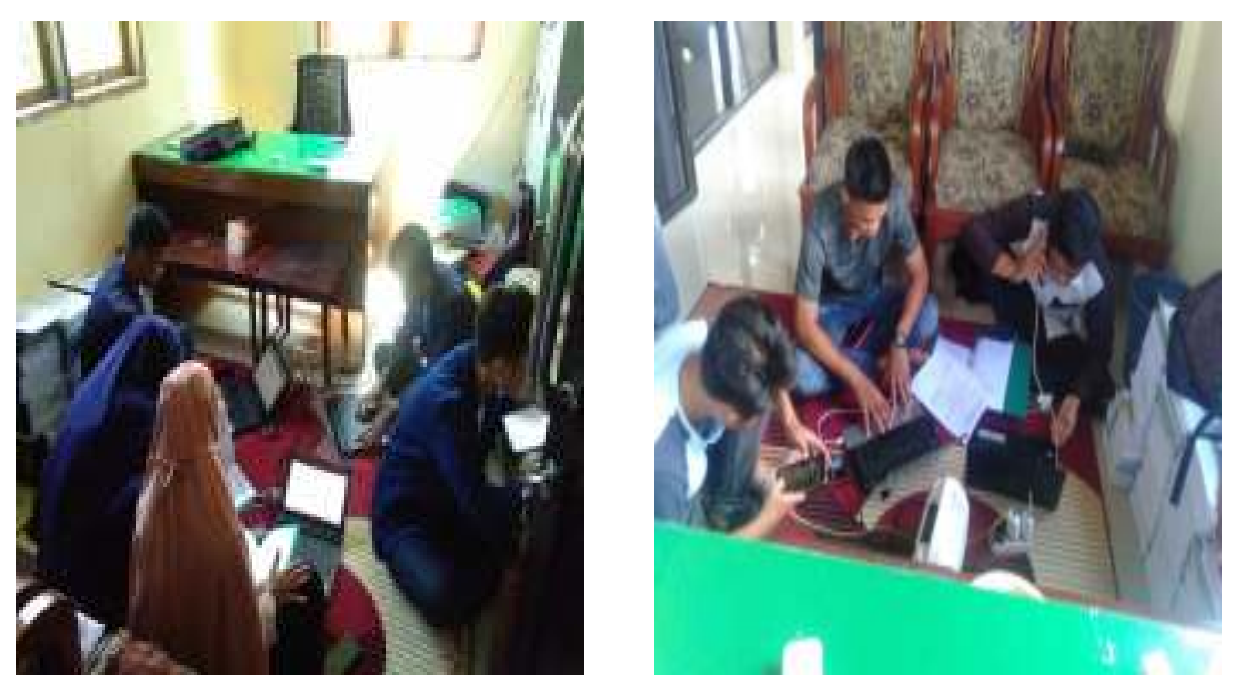


\section{GAMBARAN IPTEK}

Adapun gambaran IPTEK dalam program pengabdian masyarakat ini yaitu dengan pelatihan pembuatan Website Desa sebagai promosi desa dengan harapan akan mempermudah dalam mengenalkan potensi-potensi, maupun administrasi pelayanan publik yang ada di Desa Kanie.

\section{HASIL DAN PEMBAHASAN}

\section{Kondisi Geografis}

Desa Kanie adalah salah satu dari 12 Desa/ kelurahan yang ada di Kabupaten Sidenreng Rappang berada di Kecamatan Maritenggae, dengan kondisi topografi yang relatif datar berada di tepi jalan poros. Secara geografis Desa Kanie terletak di S 0402'64,8'danE 119³7'53,4". Adapun Desa Kanie terbagi menjadi dua Dusun yaitu Dusun Kanie 1 dan Dusun Labempa.

Secara administratif pemerintahan, Wilayah Desa Kanie berbatasan wilayah dengan :

- Sebelah Utara berbatasan dengan kelurahan Kadidi Kecamatan Pancarijang

- Sebelah selatan berbatasan dengan Desa Sereang

- Sebelah Barat berbatasan dengan Desa Carawali

- Sebelah Timur berbatasan dengan Kelurahan Kanyuara Kecamatan Watang Sidenreng

\section{Rancangan Website dan Implementasi Sistem}

Perancangan Website di Kantor Desa Kanie dilakukan oleh tim BSI dan Dosen pembimbing Universitas Muhammadiyah Sidenreng Rappang diusulkan aplikasi berbasis Web yang diharapkan dapat bekerja sesuai yang direncanakan yaitu Optimalisasi Web Desa, Arsip Digital, Dan Manajemen Bumdes di Kantor Desa Kanie. Adapun alamat Website dapat diakses melalui laman http://kanie.ums.pw/. Implementasi dari Website desa secara umum dijelaskan sebagai berikut: 
Tampilan Halaman Website

Gambar 4 dan 5. Tampilan Halaman Website Desa Kanie
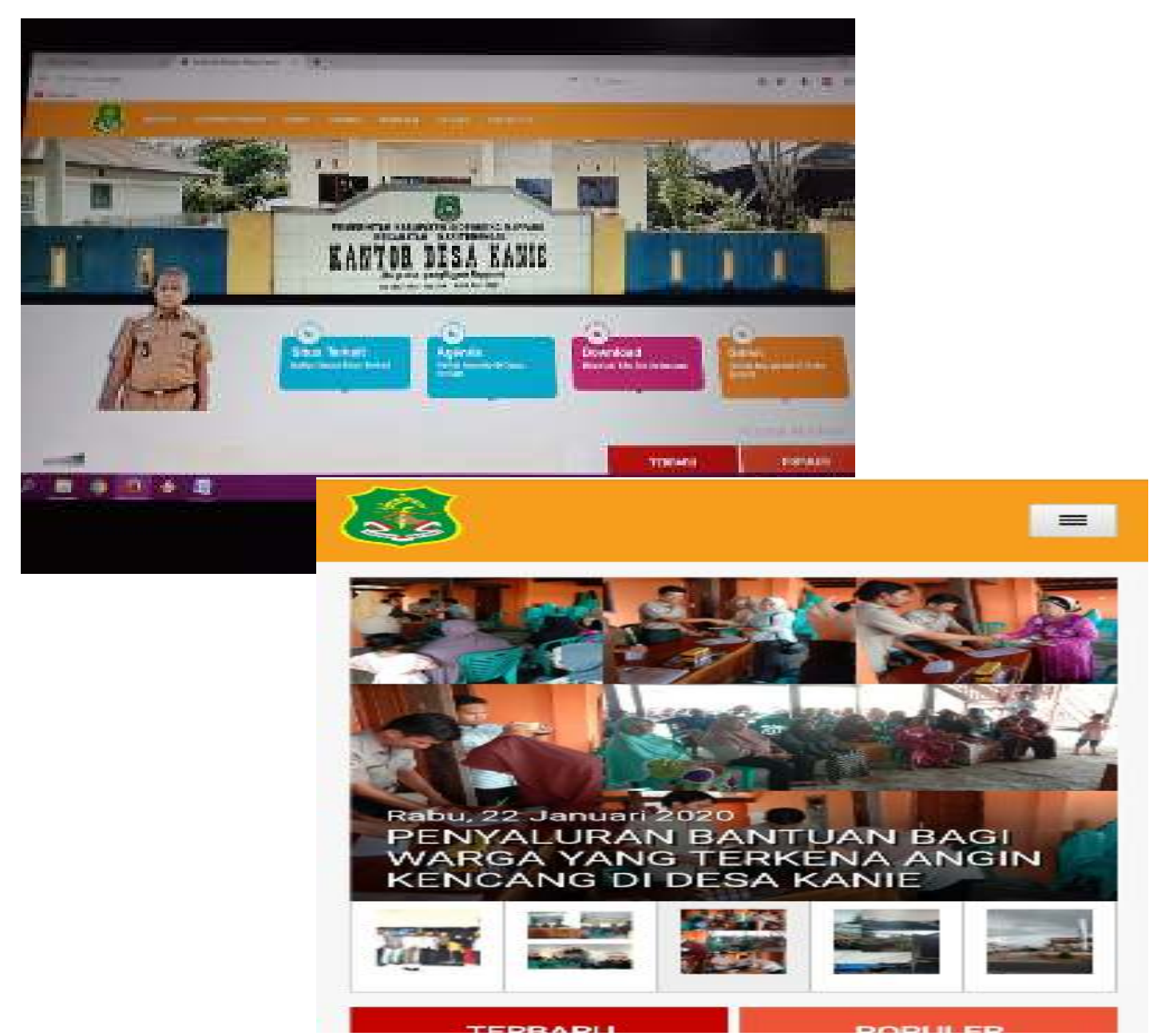

Gambar 6 dan 7. Tampilan Halaman Login Untuk Administrator dan Homepage

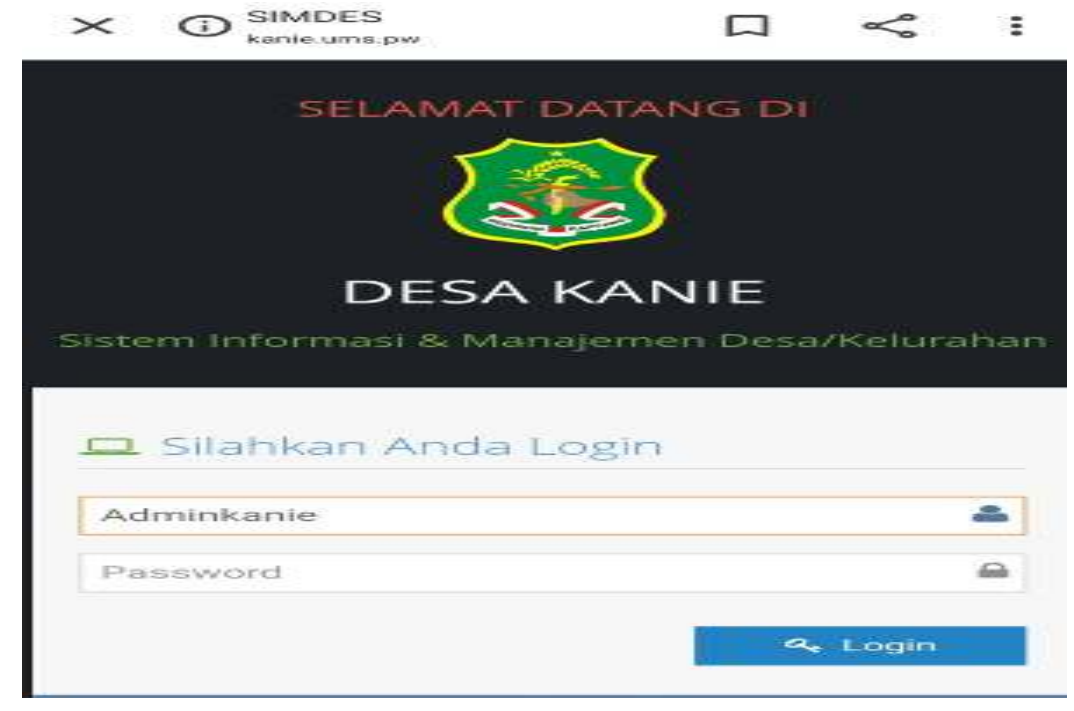




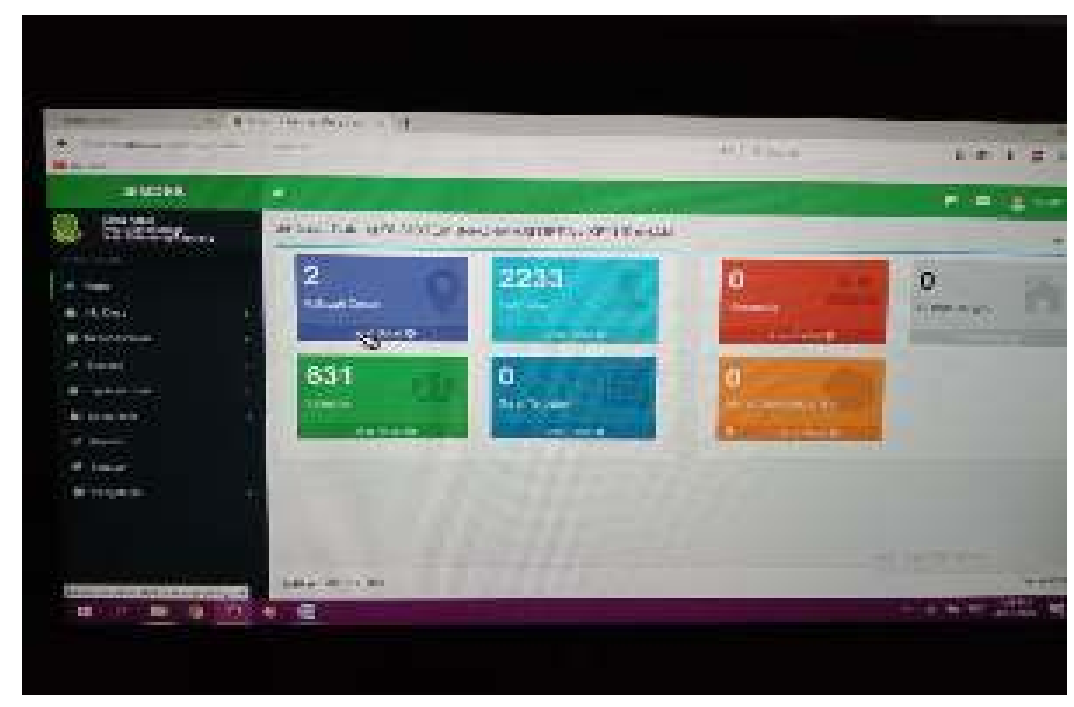

Gambar 8 dan 9. Tampilan Model Penyajian Data Statistik Kependudukan

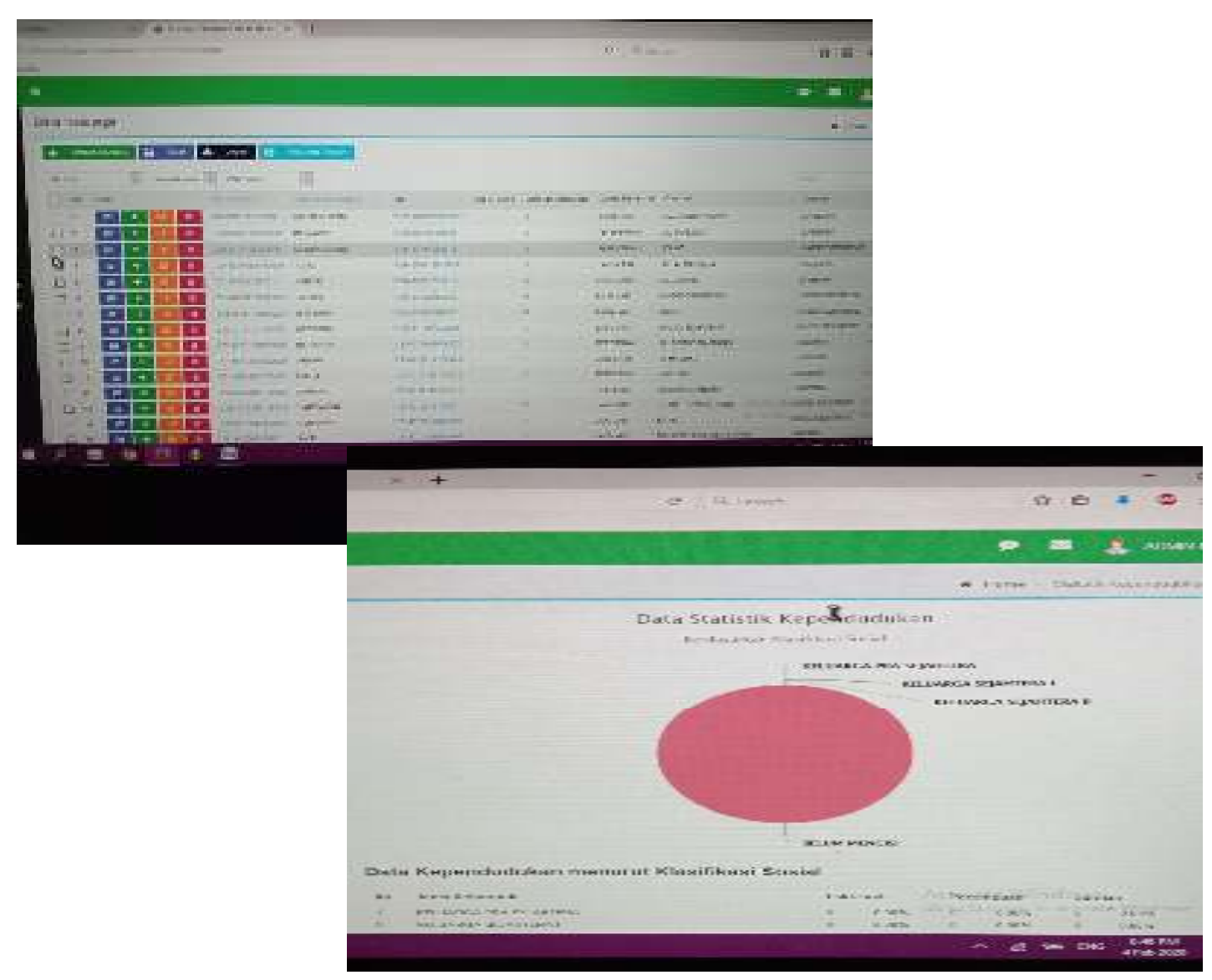




\section{KESIMPULAN}

Pelaksanaan program Magang dengan tema "Optimalisasi Web Desa, Arsip Digital, dan Manajemen Bumdes" Dengan adanya Website Desa ini dapat membantu terpublikasinya kegiatan-kegiatan, mengenalkan potensi-potensi, maupun administrasi pelayanan publik yang ada di Desa Kanieyang sebelumnya hanya dikenal oleh masyarakat sekitar saja. Sehingga permasalahan-permasalahan yang ada dapat diketahui oleh pemerintah dan akan dapat menjadi modal baik bagi pemerintah Desa untuk membawa Desa Kanie menuju Desa yang lebih maju. Diharapkan akan tetap ada monitoring yang berkelanjutan terhadap implementasi kegiatan ini serta menjaga keamanan data Website dengan selalu membackup data yang diinput.

\section{REFERENCES}

Abdul Kadir. 2003. Pengenalan Sistem Informasi. Andi. Yogyakarta

Akhmad, I., Mustanir, A., \& Ramadhan, M. R. (2018). Pengaruh Pemanfaatan Tekhnologi Informasi dan Pengawasan Keuangan Daerah Terhadap Kualitas Laporan Keuangan Kabupaten Enrekang. In Prosiding Konferensi Nasional Ke7 Asosiasi Program Pascasarjana Perguruan Tinggi Muhammadiyah Aisyiyah (APPPTMA). Jilid 2. Sosial Politik dan Ekonomi (pp. 89-103). Retrieved from http://asosiasipascaptm.or.id/index.php/publikasi/konferensi-appptm-ke-7meningkatkan-kualitas-dan-kuantitas-jurnal-ilmiah

Barisan, B., Ramadhan, M. R., \& Mustanir, A. (2017). Sidenreng Rappang Versus Masyarakat Ekonomi Asean. In The 2nd Journal of Government and Politics International Conference (Vol. II, pp. 258 - 262). Yogyakarta: Penerbit Program Pascasarjana Universitas Muhammadiyah Yogyakarta. Retrieved from http://jksg.umy.ac.id/proceeding-2nd-jgp/

Damis Dadda, A., Mustanir, A., Nilwana, A., \& Ahmad, J. (2019). Pengaruh Kepemimpinan Lurah Perempuan Terhadap Stabilitas Kamtibmas Di Kelurahan Rappang Kabupaten Sidenreng Rappang. In Konferensi Nasional Ke-8 Asosiasi Program Pascasarjana Perguruan Tinggi Muhammadiyah Aisyiyah (APPPTMA) (pp. 378-383). Medan: Program Pascasarjana Universitas Muhammadiyah Yogyakarta. Retrieved from http://asosiasipascaptm.or.id/index.php/publikasi/prosiding-konferensi-nasionalappptma-ke-8

Dawabsheh, M., Mustanir, A., \& Jermsittiparsert, K. (2020). School Facilities as a Potential Predictor of Engineering Education Quality: Mediating Role of Teaching Proficiency and Professional Development. TEST Engineering \& Management, 82, 3511-3521. Retrieved from http://www.testmagzine.biz/index.php/testmagzine/article/view/1417 
Ibrahim, M., \& Mustanir, A. (2019). 000166480. Indonesia. Retrieved from https://ehakcipta.dgip.go.id/index.php/c?code=QxyjBjWNj\%2FNkAjQbUK1azX43ghG

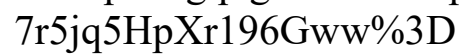

Irwan, I., Latif, A., Sofyan, S., Mustanir, A., \& Fatimah, F. (2019). Gaya Kepemimpinan, Kinerja Aparatur Sipil Negara dan Partisipasi Masyarakat Terhadap Pembangunan Di Kecamatan Kulo Kabupaten Sidenreng Rappang. MODERAT: Jurnal Ilmiah Ilmu Pemerintahan Universitas Galuh Ciamis, 5(1), 32-43. Retrieved from https://jurnal.unigal.ac.id/index.php/moderat/article/view/1900

Kholifah R, E., \& Mustanir, A. (2019). Food Policy and Its Impact on Local Food. Journal of Asian Review of Public Affairs and Policy (ARPAP), 4(3), 1-15. https://doi.org/http://dx.doi.org/10.222.99/arpap/2019.57

Latif, A., Irwan, I., Mustanir, A., Ahmad, J., \& Sakkir, G. (2019). Village Government Leadership Towards Optimizing Society Participation in Development Planning, 367(ICDeSA), 12-16.

Latif, A., Irwan, I., Rusdi, M., Mustanir, A., \& Sutrisno, M. (2019). Partisipasi Masyarakat Dalam Pembangunan Infrastruktur Di Desa Timoreng Panua Kecamatan Panca Rijang Kabupaten Sidenreng Rappang. MODERAT: Jurnal Ilmiah Ilmu Pemerintahan Universitas Galuh Ciamis, 5(1), 1-15. Retrieved from https://jurnal.unigal.ac.id/index.php/moderat/article/view/1898

Latif, A., Mustanir, A., \& Irwan, I. (2019). 000154310. Indonesia. Retrieved from https://e-

hakcipta.dgip.go.id/index.php/c?code=O5WBq8jk6ojHBGsHZ0IcyWk9iSxPQ C0AY1BCTI4WlXY\%3D

Latif, A., Mustanir, A., \& Irwan, I. (2019). Kepemimpinan Pemerintahan Desa, Partisipasi Masyarakat dan Perencanaan Pembangunan. Rappang: CV. Penerbit Qiara Media.

Mustanir, Ahmad; Abadi, P. (2016). PARTISIPASI MASYARAKAT DALAM MUSYAWARAH RENCANA PEMBANGUNAN DI KELURAHAN KANYUARA KECAMATAN WATANG SIDENRENG KABUPATEN SIDENRENG RAPPANG. Jurnal Politik Profetik, 5(2), 247-261. Retrieved from http://journal.uin-alauddin.ac.id/index.php/jpp/article/viewFile/4347/3986

Mustanir, Ahmad; Ali, Akhwan; Yasin, A. B. (2018). Transect on Participatory Development Planning in Sidenreng Rappang Regency. In International Conference on Environmental Governance (ICONEG 2018). Preprint. Makassar: IOP Conference Series: Earth and Environmental Science.

Mustanir, A. (n.d.). Pemberdayaan Masyarakat Kewirausahaan. Retrieved from https://www.researchgate.net/publication/331311483_Pemberdayaan_Masyarak at Kewirausahaan

Mustanir, A. (2015). Pemberdayaan Masyarakat Berbasis Bina Desa.

Mustanir, A. (2016a). Magang Mahasiswa. Rappang. Retrieved from https://www.academia.edu/38492683/Panduan_magang_STISIP_Muhammadiy ah_Rappang_2015_2016.pdf

Mustanir, A. (2016b). Perencanaan Mewujudkan Kehidupan Pemerintahan dan Sosial Yang Islami di Desa Tonrong Rijang Kabupaten Sidenreng Rappang. Prosiding Seminar Nasional, Reformasi Dan Inovasi Tata Kelola Pemerintahan, $289 \quad-\quad 307 . \quad$ Retrieved from https://www.researchgate.net/publication/330101808_Perencanaan_Mewujudka 
n_Kehidupan_Pemerintahan_dan_Sosial_Yang_Islami_di_Desa_Tonrong_Rija ng_Kabupaten_Sidenreng_Rappang

Mustanir, A. (2016 c). Perencanaan Mewujudkan Kehidupan Pemerintahan dan Sosial Yang Islami di Desa Tonrong Rijang Kabupaten Sidenreng Rappang. In Budiman, R. Kalalinggi, Burhanudin, \& J. B (Eds.), Seminar Nasional, Reformasi dan Inovasi Tata Kelola Pemerintahan (pp. 289-307). Samarinda: FISIP UNIVERSITAS MULAWARMAN. Retrieved from https://www.researchgate.net/publication/330101808_Perencanaan_Mewujudka n_Kehidupan_Pemerintahan_dan_Sosial_Yang_Islami_di_Desa_Tonrong_Rija ng_Kabupaten_Sidenreng_Rappang

Mustanir, A. (2017a). Deskripsi Tentang Keamanan Di Gedung dan Jalanan Kota Kuala Lumpur. Kuala Lumpur. Retrieved from https://www.researchgate.net/publication/331064740_Deskripsi_Tentang_Keam anan_Di_Gedung_dan_Jalanan_Kota_Kuala_Lumpur

Mustanir, A. (2017b). Pemberdayaān Bāan Usăha Milik Desa Melalui Kelompok Ekonomi Kewirausahaan Secara Partisipatif. Rappang. Retrieved from https://www.researchgate.net/publication/331065123_Pemberdayaan_Badan_U saha_Milik_Desa_Melalui_Kelompok_Ekonomi_Kewirausahaan_Secara_Partis ipatif

Mustanir, A. (2018a). Pemanfaatan Teknologi Informasi Dalam Optimalisasi Pelayanan Publik dan Potensi Desa Sereang. Rappang. Retrieved from https://www.researchgate.net/publication/331064206_Pemanfaatan_Teknologi_ Informasi_Dalam_Optimalisasi_Pelayanan_Publik_dan_Potensi_Desa_Sereang

Mustanir, A. (2018b). Pemberdayaan Perempuān Anggota Badan Usaha Milik Desa dengan Pemanfaatan Lahan Kebun Bibit Desa. Rappang. Retrieved from https://www.researchgate.net/publication/331071158 Pemberdayaan Perempua n_Anggota_Badan_Usaha_Milik_Desa_dengan_Pemanfaatan_Lahan_Kebun_B ibit_Desa

Mustanir, A. (2019). 000150190. Indonesia. Retrieved from https:/ehakcipta.dgip.go.id/index.php/c?code=NZB4Zr9LastRL1uAJcM6\%2BCpN5w Q\%2FsqJMYJhsuRSZ\%2BHQ\%3D

Mustanir, A. (2019a). Budaya Politik Islam Dalam Kehidupan Pemerintahan di Kota Makassar.

Mustanir, A. (2019b). Referensi Article Partisipasi Masyarakat Perencanaan Pembangunan Dan Pemberdayaan Masyarakat, (May).

Mustanir, A., \& Abadi, P. (2017). PARTISIPASI MASYARAKAT DALAM MUSYAWARAH RENCANA PEMBANGUNAN DI KELURAHAN KANYUARA KECAMATAN WATANG SIDENRENG KABUPATEN SIDENRENG RAPPANG. Jurnal Politik Profetik, 5(2), 247-261. Retrieved from http://journal.uin-alauddin.ac.id/index.php/jpp/article/viewFile/4347/3986

Mustanir, A., Abadi, P., \& Nasri, A. (2016). Participation of Ethnic Community Towani Tolotang in Deliberation of Development Plan. In International Conference on Ethics in Governance (ICONEG 2016) (Vol. 84, pp. 356 - 359). Makassar: Atlantis Press. https://doi.org/10.2991/iconeg-16.2017.79

Mustanir, A., Ali, A., \& Yasin, A. (2018). Transect on Participatory Development Planning in Sidenreng Rappang Regency. In IOP Conference Series: Earth and Environmental Science. Maka.

Mustanir, A., Barisan, B., \& Hamid, H. (2017). Participatory Rural Appraisal As The 
Participatory Planning Method Of Development Planning. In Proceedings Indonesian Association for Public Administration (IAPA) International Conference Towards Open Government: Finding the Whole Government Approach (pp. 77-84). Retrieved from http://www.fisip.unair.ac.id

Mustanir, A., \& Darmiah, D. (2016). IMPLEMENTASI KEBIJAKAN DANA DESA DAN PARTISIPASI MASYARAKAT DALAM PEMBANGUNAN DI DESA TETEAJI KECAMATAN TELLU LIMPOE KABUPATEN SIDENRENG RAPPANG. Jurnal Politik Profetik, 4(2), 225-238. Retrieved from http://journal.uin-alauddin.ac.id/index.php/jpp/article/view/2749

Mustanir, A., Dema, H., Syarifuddin, H., Meity, K., \& Wulandari, S. (2018). Pengaruh Motivasi dan Partisipasi Masyarakat terhadap Pembangunan di Kelurahan Lalebata Kecamatan Panca Rijang Kabupaten Sidenreng Rappang. Jurnal Ilmiah Clean Government (JCG), 2(1), 27-39. Retrieved from http://lonsuit.unismuhluwuk.ac.id/index.php/clean/article/view/212

Mustanir, A., Hamid, H., \& Syarifuddin, R. N. (2019a). Pemberdayaan Kelompok Masyarakat Desa Dalam Perencanaan Metode Partisipatif. MODERAT: Jurnal Ilmiah Ilmu Pemerintahan, 5(3), 227-239. Retrieved from https://jurnal.unigal.ac.id/index.php/moderat/article/view/2677

Mustanir, A., Hamid, H., \& Syarifuddin, R. N. (2019b). Pemberdayaan Kelompok Wanita Tani di Kawasan Perdesaan Prioritas Nasional. In Seminar Nasional Program Pengabdian Masyarakat 2019. Yogyakarta.

Mustanir, A., Hamid, H., \& Syarifuddin, R. N. (2019c). Pemberdayaan Kelompok Wanita Tani Di Kawasan Perdesaan Prioritas Nasional. In S. Sakir, B. Nugroho, \& W. Fatoni (Eds.), Prosiding Seminar Nasional Program Pengabdian Masyarakat 2019 (pp. 1606-1618). Yogyakarta: Lembaga Penelitian, Publikasi dan Pengabdian Masyarakat (LP3M) Universitas Muhammadiyah Yogyakarta. Retrieved from http://semnasppm.umy.ac.id/

Mustanir, A., Hamid, H., \& Syarifuddin, R. N. (2019d). Perencanaan Partisipatif Dalam Pemberdayaan Masyarakat Kelompok Wanita Tani. (Dema, Ed.). Rappang: CV. Penerbit Qiara Media.

Mustanir, A., \& Jaya, I. (2016a). PENGARUH KEPEMIMPINAN DAN BUDAYA POLITIK TERHADAP PERILAKU PEMILIH TOWANI TOLOTANG DI KECAMATAN MARITENGNGAE KABUPATEN SIDENRENG RAPPANG. Jurnal Politik Profetik, 4(1), 84-97. Retrieved from http://journal.uinalauddin.ac.id/index.php/jpp/article/view/2741\#

Mustanir, A., \& Jaya, I. (2016b). PENGARUH KEPEMIMPINAN DAN BUDAYA POLITIK TERHADAP PERILAKU PEMILIH TOWANI TOLOTANG DI KECAMATAN MARITENGNGAE KABUPATEN SIDENRENG RAPPANG. Jurnal Politik Profetik, 04(1), 84-97. Retrieved from http://journal.uinalauddin.ac.id/index.php/jpp/article/view/2741\#

Mustanir, A., Jermsittiparset, K., Ali, A., Hermansyah, S., \& Sakinah, S. (2020). Village Head Leadership and Bureaucratic Model Towards Good Governance In Sidenreng Rappang. In Hasanuddin International Conference on Social and Political Sciences (HICOSPOS) 2019. Theme: Social and Climate Changes in 5.0 Society. Makassar: European Alliance for Innovation (EAI). https://doi.org/http://dx.doi.org/10.4108/eai.21-10-2019.2291532

Mustanir, A., \& Jusman. (2016). IMPLEMENTASI KEBIJAKAN DAN EFEKTIVITAS PENGELOLAAN TERHADAP PENERIMAAN RETRIBUSI 
DI PASAR LANCIRANG KECAMATAN PITU RIAWA KABUPATEN SIDENRENG RAPPANG. Jurnal Ilmiah Akmen, 13(3), 542-558. Retrieved from https://e-jurnal.stienobel-indonesia.ac.id/index.php/akmen/article/view/69

Mustanir, A., Justira, N., Sellang, K., \& Muchtar, A. I. (2018). Democratic Model On Decision-Making At Deliberations Of Development Planning. International Conference on Government Leadership and Social Science (ICOGLASS). Demanding Governance Accountability and Promoting Democratic Leadership for Public Welfare Achievement, 110 - 115. Retrieved from https://www.researchgate.net/publication/330090538_Democratic_Model_On_ Decision-Making_At_Deliberations_Of_Development_Planning

Mustanir, A., \& Lubis, S. (2017). Participatory Rural Appraisal in Deliberations of Development Planning. In International Conference On Democracy, Accountability, and Governance (ICODAG 2017) (Vol. 163, pp. 316-319). Pekanbaru: Atlantis Press. https://doi.org/10.2991/icodag-17.2017.60.

Mustanir, A., Madaling, M., Uceng, A., Kasau, M. N. R., Barisan, B., \& Andriani, D. (2019). Karakteristik Kepemimpinan Lurah Terhadap Partisipasi Masyarakat Dalam Musyawarah Perencanaan Pembangunan Di Kelurahan Duampanua Kecamatan Baranti Kabupaten Sidenreng Rappang. Jurnal Ilmiah Clean Government (JCG), 2(2), 145-172.

Mustanir, A., Mustanir, A., Mustanir, A., Mustanir, A., Mustanir, A., Mustanir, A., ... On, M. (2019). Referensi Rujukan PowerPoint, II(2017), 258-262.

Mustanir, A., Ramadhan, M. R., Razak, M. R. R., Lukman, L., Sapri, S., \& Takhrim, T. (2019). Peranan camat dan Komunikasi Pemerintahan Terhadap Perencanaan Pembangunan di Kecamatan Malua Kabupaten Enrekang. Jurnal Ilmiah Clean Government (JCG), 2(2), 94-114.

Mustanir, A., \& Razak, M. R. R. (2017). Nilai Sosial Budaya Pada Partisipasi Masyarakat Etnik Towani Tolotang Dalam Musyawarah Rencana Pembangunan. In Prosiding Konferensi Nasional Ke-6 Asosiasi Program Pascasarjana Perguruan Tinggi Muhammadiyah Aisyiyah (APPPTMA) (pp. 17). Pare Pare: Program Pascasarjana Universitas Muhammadiyah Yogyakarta. Retrieved from http://asosiasipascaptm.or.id/index.php/publikasi/prosidingkonferensi-nasional-appptma-ke-6

Mustanir, A., \& Rusdi. Muhammad. (2019). Participatory Rural Appraisal (PRA) Sebagai Sarana Dakwah Muhammadiyah Pada Perencanaan Pembangunan Di Kabupaten Sidenreng Rappang. In Konferensi Nasional Ke-8 Asosiasi Program Pascasarjana Perguruan Tinggi Muhammadiyah Aisyiyah (APPPTMA) (pp. 378-383). Medan: Penerbit Program Pascasarjana Universitas Muhammadiyah Yogyakarta.

Retrieved

from http://asosiasipascaptm.or.id/index.php/publikasi/prosiding-konferensi-nasionalappptma-ke-8

Mustanir, A., Samad, Z., Ibrahim, M., Jabbar, A., \& Juniati, J. (2019). Kepemimpinan Lurah Terhadap Pemberdayaan Masyarakat Di Kelurahan Lautang Benteng Kabupaten Sidenreng Rappang. JSPG: Journal of Social Politics and Governance, 20-39. https://doi.org/https://doi.org/10.24076/JSPG.2019v1i2.5460

Mustanir, A., Sellang, K., Ali, A., Madaling, M., \& Mutmainna, M. (2018). PERANAN APARATUR PEMERINTAH DESA DAN PARTISIPASI MASYARAKAT DALAM MUSYAWARAH PERENCANAAN 
PEMBANGUNAN DI DESA TONRONGNGE KECAMATAN BARANTI KABUPATEN SIDENRENG RAPPANG. Jurnal Ilmiah Clean Government (JCG), 2(1), 67-84. Retrieved from http://lonsuit.unismuhluwuk.ac.id/index.php/clean/article/view/213

Mustanir, A., \& Yasin, A. (2018). Community Participation in Transect on Development Planning. Jurnal Ilmiah Ilmu Administrasi Publik: Jurnal Pemikiran Dan Penelitian Administrasi Publik (JIAP), 8(2), 137-146. https://doi.org/https://doi.org/10.26858/jiap.v8i2.7994

Mustanir, A., Yasin, A., Irwan, I., \& Rusdi, M. (2018). Potret Irisan Bumi Desa Tonrong Rijang Dalam Transect Pada Perencanaan Pembangunan Partisipatif. MODERAT: Jurnal Ilmiah Ilmu Pemerintahan, 4(4), 1-14. Retrieved from https://jurnal.unigal.ac.id/index.php/moderat/article/view/1775

Parinya, S., Jermsittiparsert, K., \& Mustanir, A. (2019). What Determine the Organizational Citizenship Behavior in Indonesian Agriculture Manufacturing Firms? International Journal of Psychosocial Rehabilitation, 23(4), 778-792. https://doi.org/10.37200/IJPR/V23I4/PR190409

Razak, M. R. R., Dahong, M., Ahmad, J., Dema, H., \& Mustanir, A. (2018). The Effect of Siri's Marriage on Government Administration. International Journal of Sciences: Basic and Applied Research (IJSBAR), 42(3), 171-184. Retrieved from

http://gssrr.org/index.php?journal=JournalOfBasicAndApplied\&page=article\&o $\mathrm{p}=$ view\&path $\% 5 \mathrm{~B} \% 5 \mathrm{D}=9484$

Saidiman, S., Lubis, S., Razak, M. R. R., \& Mustanir, A. (2019). Pengaruh Kepemimpinan dan Disiplin Kerja Terhadap Kinerja Birokrasi Pelayanan Publik pada Kantor Kecamatan Buntu Batu Kabupaten Enrekang. In Prosiding Konferensi Nasional Ke-9 Asosiasi Program Pascasarjana Perguruan Tinggi Muhammadiyah Aisyiyah (APPPTMA) (pp. 525-540). Malang: Program Pascasarjana Universitas Muhammadiyah Yogyakarta. Retrieved from http://www.appptma.org/wp-content/uploads/2020/02/525-2686-4312.pdf

Samad, Z., Mustanir, A., \& Pratama, M. Y. (2019). Partisipasi Masyarakat Dalam Musyawarah Rencana Pembangunan Untuk Mewujudkan Good Governance Kabupaten Enrekang. MODERAT: Jurnal Ilmiah Ilmu Pemerintahan, 5(4), 377-393. Retrieved from https://jurnal.unigal.ac.id/index.php/moderat/article/view/3014

Sapri, S., Mustanir, A., Ibrahim, M., Adnan, A. A., \& Wirfandi, W. (2019). Peranan Camat dan Partisipasi Masyarakat Dalam Musyawarah Perencanaan Pembangunan Di Kecamatan Enrekang Kabupaten Enrekang. MODERAT: Jurnal Ilmiah Ilmu Pemerintahan, 5(2), 33-48. Retrieved from https://jurnal.unigal.ac.id/index.php/moderat/article/view/2127

Sellang, Kamaruddin; Ahmad, Jamaluddin; Mustanir, A. (2019). Strategi dalam peningkatan kualitas pelayanan publik. (Q. Media, Ed.) (1st ed.). Rappang: CV. Penerbit Qiara Media. Retrieved from https://www.researchgate.net/publication/335000572_Strategi_dalam_Peningka tan Kualitas Pelayanan Publik Dimensi Konsep Indikator dan Implementas inya? _sg=1Iz-

1Rq6ōZZhw1LW1F4FsWj679IsZXHWNBS6aQj1Y01DOWpb2qAhpNSEDg29 L28NxSu6-asTSMDE8O-

eTsfwAb5Q11CNgOBtmPO2m9UA.u76ku9orzaS1VzABirs590BoZZiRGmuH 
DoF7qAdPMPGugda64e68NHN823oS9G_kaeYbBbZYNWqcNgtfe0gigQ

Sellang, K., \& Mustanir, A. (2019). 000172479. Indonesia. Retrieved from https://ehakcipta.dgip.go.id/index.php/c?code=dB8ifXCS8G1RlszeoGMCiaLZGwerfdc Lz4Ua1JEBLCk\%3D

Uceng, A., Ali, A., Mustanir, A., \& Nirmawati, N. (2019). Analisis Tingkat Partisipasi Masyarakat Terhadap Pembangunan Sumber Daya Manusia Di Desa Cemba Kecamatan Enrekang Kabupaten Enrekang. Jurnal MODERAT, 5(2), 117. Retrieved

https://jurnal.unigal.ac.id/index.php/moderat/article/view/2125

Uceng, A., Erfina, E., Mustanir, A., \& Sukri, S. (2019). Partisipasi Masyarakat Dalam Musyawarah Perencanaan Pembangunan Di Desa Betao Riase Kecamatan Pitu Riawa Kabupaten Sidenreng Rappang. MODERAT: Jurnal Ilmiah Ilmu Pemerintahan, 5(2), 18-32. Retrieved from https://jurnal.unigal.ac.id/index.php/moderat/article/view/2126

Uceng, A., Nadirah, N., \& Mustanir, A. (2019). 000166978. Indonesia. Retrieved from https://ehakcipta.dgip.go.id/index.php/c?code=ZBTRSI6Boitu4\%2B\%2Be\%2Fp10BXV f8OVtQL\%2FDKUrNULsircY\%3D

Sutabari. 2012. Konsep Sistem Informasi. Andi. Yogyakarta

https://profiilkanie.blogspot.com/2017/12/kondisi-geografis-danadministrasi.html

*) Corresponding Author 